\title{
"School's Out, But Class's On", The Largest Online Education in the World Today: Taking China's Practical Exploration During The COVID-19 Epidemic Prevention and Control as An Example
}

\author{
Longjun Zhou, ${ }^{1,2}$ Fangmei $\mathrm{Li}^{3}{ }^{3}$ Shanshan $\mathrm{Wu},{ }^{3}$ Ming Zhou ${ }^{4}$
}

1. Jiangsu Second Normal University, Nanjing 211200, Jiangsu, China

2. Engineering Research Center of Digital Learning Support Technology, Ministry of Education, Changchun 130000, Jilin, China

3. Nanjing Dianji Institute of Psychological Education, Nanjing 210000, Jiangsu, China 4. Jiangnan School, Zhenjiang 212008, Jiangsu, China

\begin{abstract}
Online education is a hot topic that is widely concerned in various countries today. In the era of mobile internet, countries around the world have made various effective attempts at online education, but online education is more of a supplement to school education, and largescale normal online education lacks cases. The "School's Out, But Class's On" campaign launched by the Chinese government during the COVID-19 epidemic created a large-scale, normal online education application. We analyzed the background of this large-scale online education, clarify the foundation of large-scale online education, and reveal the impact of the largest online education activities on society and education.
\end{abstract}

Best Evid Chin Edu 2020; 4(2):501-519.

Doi: 10.15354/bece.20.ar023.

Keywords: Online Education; COVID-19 Epidemic; School's Out, But Class's On; Practice; Foundation

\footnotetext{
About the Authors: Longjun Zhou, Professor, Jiangsu Second Normal University, Nanjing 211200, Jiangsu; and Research Scientist, Engineering Research Center of Digital Learning Support Technology, Ministry of Education, Changchun 130000, Jilin, China. Email: 294437034@qq.com.
} 
$\mathrm{E}$ -LEARNING, distance education or online learning, refers to the method of content dissemination and rapid learning through the application of information technology and Internet technology. The "e" of e-Learning stands for electronic learning, efficient learning, exploratory learning, experiential learning, expanded learning, extended learning, easy-to-use learning, and enhanced learning. The United States is the birthplace of e-learning. After 1998, e-Learning has been being spread worldwide, and has rapidly expanded from North America and Europe to Asia.

Online education is one of the important education methods today. It has developed rapidly around the world and has gradually become an important category of school education. Countries around the world are actively exploring how to effectively educate students through the Internet, and many good examples of online education have emerged, resulting in many valuable experiences in online education.

Although online education is developing rapidly around the world, more applications of online education are used as a supplement to regular school education. In the normalized education and teaching practice, more students go to schools to participate in traditional classroom teaching, and large-scale online education lacks practical application scenarios.

The outbreak of COVID-19 in Wuhan, China, at the end of 2019, was a major public health emergency that had the fastest spread, the widest scope of infection, and the most difficult to prevent and control in China since its establishment (Xinhuanet, 2020). Affected by the epidemic, the government requires departments at all levels to organize forces to limit or stop crowd gathering, and requires non-essential enterprises to suspend production and business operations, and normal economic and social activities were greatly affected (Guangming.com, 2020). The World Health OrganizationChina Joint Expert Expedition calls the powerful public health measures China has taken in response to the COVID-19 epidemic, which may be "the most ambitious, flexible and active disease control in human history" (People's Network, 2020).

While blocking the spread of the COVID-19 epidemic to schools, in order to reduce the impact of the epidemic on education, since February 4, 2020, the Leading Group of the Ministry of Education of China to respond to the COVID-19 epidemic has issued the "About Guiding Opinions on Online Teaching Organization and Management of General Colleges and Universities during the Period, Notice on Supporting Education and Teaching with Information Technology during Epidemic Prevention and Control, and Several Suggestions on Targeted Teacher Work during Epidemic Prevention and Control Notice". It is proposed here that during the COVID-19 epidemic,

About the Authors: Shanshan Wu, Nanjing Dianji Institute of Psychological Education, Nanjing 210000, Jiangsu, China.Email: 378233525@qq.co.

Ming Zhou, Jiangnan School, Zhenjiang 212008, Jiangsu, China.Email: 929883506@qq.com.

Correspondence to: Fangmei Li, Nanjing Dianji Institute of Psychological Education, Nanjing 210000, Jiangsu, China.Email: $1037576462 @ q q . c o m$.

Conflict of Interests: None. 
schools use internet platforms to guide students to realize "School's Out, But Class's On", i.e., "School is closed, but student learning is continuing online" or "Online Home Study" (This refers to the Official Website of the Chinese Ministry of Education: http://en.moe.gov.cn/).

Against this background, offline education and training institutions nationwide suspended their courses, elementary and middle schools postpone the start of 2020 spring semester, and actively conducted online teaching activities such as online teaching and learning as required by the Ministry of Education. This provides necessary learning support services for elementary and middle schools students' home study, guarantees the teaching progress and teaching quality during the COVID-19 epidemic prevention and control, and achieves the goal of "School's Out, But Class's On".

Although the Chinese government's decision is an education measure that must be taken as a last resort, the activity itself has had a profound impact. According to the official data of the Ministry of Education in 2019, China has 270 million students at all levels and nearly 20 million faculty members at all levels (Ministry of Education of the People's Republic of China, 2019). So many teachers and students carry out educational activities through the Internet for a period of more than six weeks, which is a great initiative of online education in the world. Based on the implementation status of "School's Out, But Class's On", we are trying to summarize the reasons for the smooth development of large-scale online education activities based on the development results of modern education in China. The effective implementation of the preface provides reference and inspiration.

\section{Origin of Large-Scale Online Education Activities}

Due to the need to prevent and control the COVID-19 epidemic, schools postponed the start of 2020 spring semester, so students cannot study at school during normal school hours. The Ministry of Education requires local education departments and schools to do a good job of "School's Out, But Class's On" during the postponed period, to provide students with learning resources and learning support services to help solve practical difficulties. (China Education Daily, 2020)

On February 28, 2020, the Ministry of Education issued the "Notice on Coordinating in the Education System during COVID-19 Epidemic Prevention and Education Reform and Development", which states that "School's Out, But Class's On" is essentially through modern education technology. Guide online elementary and middle school students to study through online education, and replace the interruption of teaching behavior caused by the COVID-19 epidemic through online education. The relevant documents of the Ministry of Education pointed out: "School's Out, But Class's On" is a broad-based learning, and online teaching is only one of the ways. We must further improve the construction of elementary and middle schools online learning platforms, continuously enrich learning resources, and prevent normal classrooms from being copied of the teaching methods, duration and arrangements (Ministry of Education of the People's Republic of China, 2020). 
Regarding how to carry out this activity, the Ministry of Education clearly pointed out: To clarify the current teaching "what to teach" and "how to teach", and to continue to explore the organic combination of classroom teaching and online education after school. At the same time, it is proposed to "adhere to the combination of school teachers' online guidance and assistance with students' home-based self-learning" and "strengthening home-based study guidance, help students to scientifically formulate home-based learning plans, rationally select resources, and focus on developing students' autonomous learning ability (Ministry of Education of the People's Republic of China, 2020).

On March 6, 2020, the Ministry of Education issued the "Notice on the Ministry of Education's Deployment of Elementary and Middle Schools" School's Out, But Class's On “. The summary of the notice promoted the typical experiences and practices of "School's Out, But Class's On" in the previous stage of each place, and provided a reference for the next step of the work.

1. Making overall use of television and network resources to achieve complementary advantages, resource sharing, and comprehensive coverage, especially to meet the learning needs of students in remote rural areas where the network is lacking or signal is weak.

2. Coordinate curriculum learning and special education on fighting against the "epidemics", and strengthen the guidance of patriotism education. Focus on the education of advanced deeds and epidemic prevention knowledge, life education, public safety education, and mental health education as important learning content. Guide students to correctly understand the relationship between humans, society and nature, to respect the objective world, to act scientifically and rationally, and to cultivate students' patriotism, love for people, and socialism.

3. Coordinate the characteristics of online learning and the actual needs of students, prevent normal classroom teaching methods, duration, and teaching arrangements from being copied, and strengthen study guidance for different grades and disciplines.

4. Make overall use of local resources and national platforms, and guide local and schools to make good use of national elementary and middle schools network cloud platforms and China Education Television Channel 4 classroom air learning resources.

5. Coordinate the role of backbone teachers and all other teachers, organize outstanding backbone teachers for course recording, resource provision and online teaching guidance, and organize all teachers to participate in students' online learning guidance, answering questions, and home-school communication in a variety of ways.

6. Combining overall planning and active promotion with standard implementation, we pay attention to timely and standardizing online teaching behaviors. It is strictly forbidden to generally require teachers to broadcast or record classes live. Students must not be forced to "Clock In" and up- 
load learning videos on the Internet every day. Try to avoid temporary home purchase of equipment due to print assignments or study materials, which will increase the financial burden on students' families (Ministry of Education of the People's Republic of China, 2020).

After the documents of the Ministry of Education were issued, the provincial education departments actively responded and promulgated specific local implementation plans according to relevant documents of the Ministry of Education.

Taking Zhejiang Province as an example, the province actively used the advantages of informatization of basic education, and used the Internet and informatization methods to comprehensively organize and implement online education and teaching activities in elementary and middle schools in the province. According to the latest survey report by the provincial teaching and research office, $96.0 \%$ of Middle school students in Zhejiang province participated in or are participating in online teaching activities organized by the school (Zhejiang Teaching and Research Office, 2020).

The province has made clear regulations for online teaching during specific implementation (Leading Group for Prevention and Control of Pneumonia Epidemic Situation of COVID-19 Infection in Zhejiang Provincial Department of Education, 2020):

1. Adhere to the five-core educations (morality, intelligence, sports, aesthetic, and labor) and comprehensive development.

2. Push curriculum resources, electronic textbooks, previews and homework manuals, and online homework operation manuals in a timely manner.

3. Online teaching is organized by class as a unit and two-way interaction. It is mainly based on recording and broadcasting, and adopts the form of "recording + online Q \& A". Conditional schools can take the form of live broadcast + online Q \& A. After-school tutoring can take the form of on-demand or online Q \& A.

4. Scientifically and reasonably grasp the schedule of online teaching. The teaching time for each lesson is about 20 minutes in elementary school and about 30 minutes in middle school. Allow a certain amount of time for preview and practice in each class.

5. Multiple forms of homework should be arranged for online teaching, and the students' content should be examined and evaluated in a timely manner.

The local education administration departments have formulated the specific implementation plan of "School's Out, But Class's On" according to the spirit of the documents of the Ministry of Education and the education administration departments of their respective provinces.

Taking the Education Bureau of Guangzhou City, Guangdong Province as an example, on February 29, 2020, the Guangzhou Education Bureau put forward work guidelines for online learning of elementary and middle schools in the city (Guangzhou Education Bureau, 2020):

1. Adhere to the five-core educations (morality, intelligence, sports, aesthetic, and labor) at the same time and formulate online education programs. 
2. Scientifically grasp the progress and arrange work and rest reasonably.

3. Combine online and offline to avoid increasing student burden.

4. Establish "television classrooms" to do a good job in supporting the city.

5. Accurately analyze the academic situation, and ensure the connection of back to school.

6. Strengthen classified guidance and implement online education in secondary vocational schools.

7. Take measures to ensure the smooth progress of online learning.

As provinces, municipalities, and districts successively promulgated the detailed rules for online learning at home during the epidemic prevention and control period, schools in various places based on the school situation and made corresponding implementation plans based on the actual situation of the school. Elementary schools, middle schools, high schools, and universities in various places have given specific plans for "School's Out, But Class's On" during the epidemic prevention period, starting from the development needs of students in different semesters and the actual situation of the school.

Based on the online learning practices in various places, there are mainly seven online methods provided by each school: live broadcast, recording broadcast, resource package, live broadcast + recording broadcast, live broadcast + resource package, recording broadcast + resource package, live broadcast + recording broadcast + resource package, etc.

\section{The Foundation of the Largest Online Education Campaign}

Large-scale online education activities need to be guaranteed by a well-established Internet infrastructure. Without strong infrastructure, large-scale online education activities cannot be carried out. After nearly three decades of construction of the Internet in China, the Internet infrastructure has been basically improved, providing a basic guarantee for large-scale Internet education.

\section{Achievements of National and Educational Informatization}

Since the mid-1990s, the construction of the "Information Superhighway" has begun globally, the Internet has begun a large-scale commercial process, and information technology has ushered in the second wave of vigorous development (Mei, 2018). To catch up this big wave, in 1993, China established the National Economic Informatization Joint Conference chaired by Vice Premier Jiahua Zou, and established the guiding ideology of advancing the implementation of informatization projects and driving industrial development with informatization. Therefore, China's informatization construction was officially launched.

In October 2000, the Chinese government reviewed and approved the "Recommendations of the Central Committee of the Communist Party of China on Formulating the Tenth Five-Year Plan for National Economic and Social Development". The 
Tenth Five-Year Plan clearly lists "strengthening national economic and social informatization" as a major strategic, macroscopic, and policy issue that must be researched and resolved at the beginning of the 21st century (Xinhuanet, 2000). The "Tenth Five-Year Plan" Key Special Development Plan" and the "Industry Tenth FiveYear Plan Outline" have been successively promulgated, providing more specific action guidelines for accelerating the advancement of informatization.

In 2012, informatization China was identified as one of the strategic goals of the new modernized country. The Chinese government gradually promoted informatization construction from top to bottom by constructing an informatization system framework and demonstration pilots (Zhao, 2016).

In 2017, China set the development goal of "promoting the deep integration of the Internet, big data, artificial intelligence and the real economy, building a network power, digital China, and a wisdom society", opening a new era in which the network power is moving towards a network power (Xinhuanet, 2017).

After decades of development and construction, China's industrialization and informatization have made great progress. All aspects of informatization infrastructure, network scale, digital economy, and network governance have been prepared from quantitative change to qualitative change. In 2018, the number of Internet users was 829 million, the Internet covering rate was $59.6 \%$, the digital economy scale was 31.3 trillion yuan, and the proportion of GDP reached 34.8\% (Chen, 2019). The number of online government service users reached 394 million, accounting for $47.5 \%$ of the total Internet users (Yang, 2019). The total value of domestic and overseas Internet listed companies in China is 7.89 trillion CNY (China Internet Network Information Center, 2019). The development level of national informatization and its global influence continue to increase.

China's education informatization exploration initially participated in the education and teaching reform in the form of "electronic education". In 1978, the Ministry of Education issued the "Preliminary Plan on E-education Work" (discussion draft), which is the first time to deploy education informatization at the national level $(\mathrm{Hu}$, 2019). Subsequently, the Ministry of Education successively introduced such strategic plans as the "National Ninth Five-Year Plan" for electrification education, the "Action Plan for the Revitalization of Education for the 21st Century", and the "Tenth FiveYear Development Plan (Outline) for Education Informatization". This means that China is progressing from the initial stage to the rapid development stage (Zhong, et al., 2017).

With the further innovation of modern science and technology, especially the development of next-generation information technologies such as the Internet, big data, and artificial intelligence, education informatization has led to the modernization of education, which has become a strategic consensus for the development of education in China (Zhong, et al., 2017).

In 2018, the Ministry of Education released the "Action Plan for Educational Informatization 2.0", announcing that China's education informatization has entered the 2.0 stage. In the 1.0 stage of education informatization, it is mainly based on the con- 
struction of education informatization. The focus is on the construction of "three links and two platforms", that is, the realization of "broadband network for every school, high-quality resource for every class, and online learning space for everyone." And build a public service platform for education resources and a public service platform for education management (Ministry of Education of the People's Republic of China, 2012).

With the transformation and upgrading of information construction, education information construction has entered the 2.0 stage, that is, to promote the integration and innovation of information technology and education and teaching, and to reconstruct the education ecology. Put forward "taking education informatization as an endogenous variable of systemic reform of education", "promote the reform of education through the integration and innovation of technology and education and teaching", and then "build a networked, digital, intelligent, personalized, lifelong education system to build a learning society that everyone can learn, can learn everywhere, and can learn from time to time, and achieve more open, more suitable, more people-oriented, more equal, and more sustainable education." (Ministry of Education of the People's Republic of China, 2018).

The "Education Informatization 2.0 Action Plan" marks China's construction of education informatization from equipment construction to integration and application with technology and education, focusing on extending and expanding teaching content, innovative teaching methods, changing teaching evaluation, and changes through modern technology. Education supply mode to promote the ecological transformation of the education system (China Education News, 2019). In 2019, in the "China Education Modernization 2035" document, for the first time, the state raised the construction of education informatization to the height of education modernization, indicating the direction for the construction of education informatization (Xinhuanet, 2019).

With the continuous support of the country, China has continuously promoted the construction of education informatization with "three links and two platforms" as its core. China has successfully completed the "Full Coverage of Digital Educational Resources for Teaching Sites" project, which has provided teaching sites in China, including rural remote areas, with modern teaching equipment and nationally prescribed curriculum resources (Ministry of Education of the People's Republic of China, 2015). According to the official statistics of the Ministry of Education, as of 2019, 98.4\% of elementary and middle schools (including teaching sites) in China have achieved network access, and $90.1 \%$ of elementary and middle schools have multimedia classrooms, with the number reaching 3.74 million, of which $70.2 \%$ Elementary and middle schools achieve full coverage of multimedia teaching equipment; the national education resource public service system has access to 150 online platforms, which include 1 national platform, 25 provincial platforms, 52 municipal platforms, and 72 district / county platforms (Cyber Security and Informatization Leading Group of the Ministry of Education of China, 2020). In addition to the public resource platform built by the state, educational platforms such as Tencent Class, Netease Open Class, Chinese University MOOC, Homework Help, Xueersi Online School, Ape Coaching, and VIP KID are emerging. According to the "China Online Education Industry Market Outlook and In- 
vestment Strategic Planning Analysis Report", as of December 31, 2018, 11 "unicorns" were born in China's online education sector, with a total valuation of 16.95 billion US dollars (China Economic Time, 2019).

Especially after entering the 2.0 stage, China's informatization construction has paid more attention to innovation and leading China's education development, knowledge creation and cultivation of innovative talents. Maker education, STEAM education, artificial intelligence education, robot education, etc. have become important means to promote the development of education informatization. The smart learning environment to promote knowledge innovation has gradually become a new trend in the construction of learning environments. Three-dimensional (3D) resources, holographic resources, simulation resources and other intelligent learning resources that are immersive, interactive, realistic, highly intelligent, and highly experiential make learners have unprecedented new experiences (Wang, et al., 2019).

With regard to the overall improvement of information literacy, the Ministry of Education launched the National Elementary and Middle School Teachers' Information Technology Application Ability Enhancement Project 2.0 in 2019. Annually hold advanced seminars, teachers' informatization teaching ability improvement training and other activities to improve the application of education informatization (the People's Republic of China's Leading Group of Cyber Security and Informatization, 2020).

Since the 1990s, China's education informatization has been underway for 30 years. From a global perspective, breakthroughs have been made in China's education informatization work. This has created a modern education environment for $1 / 5$ of the world's population, made an important contribution to the balanced development of global education, promoted human lifelong learning, and improved population quality (Huang, 2019). In the past three decades, the achievements of national informatization construction, especially the achievements of education informatization construction, have provided a strong technical guarantee for the development of this large-scale online education activity.

\section{Colorful Teaching Resources}

The development of large-scale online education activities must be supported by colorful teaching resources suitable for students of all grades. Without suitable online teaching resources, large-scale online teaching activities will not be carried out. After more than 20 years of unremitting efforts, the construction of online teaching resources in China has also been fruitful.

With the development of information technology, in early 2000, the Ministry of Education's “Modern Distance Education Engineering Resources Construction Fundamental Education Project" was formally established. Its basic goal was to build a rich, open, national-level basic education resource library to promote comprehensive quality and provide information support for education and the realization of informatization of basic education (Zhu, 2010). Since then, China has successively released the "Schoolto-School Link" project, "Guiding Opinions on the Construction of Elementary and Middle Schools' Campus Network”, “Elementary Education Resources Metadata Speci- 
fication CELTS-42", "Requirements for the Development of Modern Distance Vocational Education Resources", and "Modern Distance Education in Rural Elementary and Middle Schools" project that put forward clearer requirements for resource construction, and launched resources such as subject resource websites, various distance education course resources, and various teaching and research topics.

At the same time, the enterprise resource library products also developed rapidly during this period. The enterprise education resource library represented by the " $\mathrm{K}$ 12 Educational Resource Library" and the Journal Library (CNKI) launched by Tsinghua Tongfang have emerged. In addition to the library of teaching materials, e-books and periodicals resources, online course resources, theme website resources, professional training resources, etc. have been launched in the market, and there is endless stream of teaching resource products $(\mathrm{Li}, 2007)$.

With the comprehensive advancement of information technology, the construction of teaching resources has entered the third stage, that is, the construction of information education resources. A series of documents have been issued around the construction of digital resources. In 2010, China clearly stated in the "Outline of the National Medium and Long-term Education Reform and Development Plan (2010-2020)" (the Ministry of Education of the People's Republic of China, 2010) that "the development and application of high-quality educational resources" and "the construction of a national education management system "As a key construction content to achieve the goal of" accelerating the process of education informatization. "In March 2012, the Ministry of Education issued the Ten-year Development Plan for Educational Informatization (2011-2020), which includes education informationization resources such as "promoting the construction and sharing of high-quality educational resources" and "building a public service platform for continuing education". The construction content is highlighted (Ministry of Education of the People's Republic of China, 2012). In 2014, five ministries and commissions, including the Ministry of Education and the Ministry of Finance, issued the "Implementation Plan for an Effective Mechanism for Enlarging the Coverage of High-Quality Educational Resources by Informatization Means", which called for accelerating the realization of "Co-construction and sharing of high-quality digital education resources, comprehensive and deep integration of information technology and education and teaching" (China Education Information Network, 2014). The "China Education Modernization 2035" issued in 2019 also clearly pointed out the need to innovate the educational service format and establish a digital education resource co-construction and sharing mechanism. The release of a series of documents puts forward goals and requirements for strengthening the construction and application of digital education resources public service system in the new era (Cai \& Chen, 2019).

In addition to teaching materials, the construction of teaching resources at this stage also includes a shift from focusing on the content of the resources to a more individualized resource development and application model that emphasizes "peopleoriented". This includes resource creation tools, resource operating environments, resource construction evaluation and reward mechanisms based on online course resources. 
Up to 2019 , the national system has extensively engaged in the gathering of high-quality resources for the entire society. A total of 457 teaching applications have been gathered in 290 units. Through the "One Teacher, One Excellent Course; One Lesson, One Excellent Teacher" activity, it attracted more than 2.28 million participating teachers, collected 3.14 million online courses, and recommended 17,312 lessons for provincial excellent courses. Selected 1,005 ministry-level excellent courses, and generated 8 million resources. These famous teachers and lessons have continuously enriched the country's construction of one-stop distance open education platform curriculum resources that support millions of students' online learning. As of 2019, the platform has 1,360 new courses in storage, 4,671 media material resources, 3265 fiveminute courses newly developed, 255 national digital learning resource centers, 7974 sub-center courses, and 95,000 media resources The number of courses has reached more than 4,800 courses (China's Ministry of Education Network Security and Informatization Leading Group, 2020). These national online course resources provided a powerful resource support for this large-scale online learning activity.

In addition to the resource construction of the national system, companies and schools everywhere have made explorations. Internet giants such as Tencent, Alibaba, ByteDance, iFlytek, and Dongshi Ideal have long been deeply involved in the education industry. In this epidemic response, in addition to providing live broadcast infrastructure, they also integrated existing educational resources with personalized learning resources, and introduced courses ranging from kindergarten to senior high school, including subjects such as Chinese, English, and mathematics. And quality education courses such as programming and thinking training (New Fortune, 2020). The school combines school-based curriculum with online resources to develop school-based curriculum resources suitable for the school. For example, Zhenjiang Experimental School in Jiangsu Province digitized school-based protocol-guided learning materials to form digital guide drafts (Xia, 2020). These have provided more targeted teaching materials for online learning during the epidemic and enriched online teaching resources.

\section{Educational Reforms Provide a Change In Concepts and Meth- ods For Online Learning}

The fundamental goal of education information construction is to promote the development of education. Educational information technology must be deeply integrated with education and teaching to truly play its expected role. The development of large-scale online education activities must be based on scientific education concepts and correct teaching concepts. Only in the continuous reform of education and teaching, can we give full play to the function of education informatization with the guidance of the correct concept of education and teaching. Since the founding of New China, the long-term education and teaching reforms have paved the way for the healthy development of education, especially the eighth reform, which began in 1999, and has profoundly affected the reform of basic education in China.

In 2001, the Ministry of Education issued the "Outline of Basic Education Curriculum Reform (Trial)". The document clearly proposed to change the tendency of the 
curriculum to place too much emphasis on knowledge transfer, emphasizing the formation of a proactive learning attitude, so that the process of acquiring basic knowledge and basic skills simultaneously becomes a process of learning to learn and forming correct values. It is necessary to change the current status of curriculum implementation with too much emphasis on acceptance of learning, rote memorization, and mechanical training, and encourage students to take an active part, be willing to explore, and be diligent in their work, and cultivate students' ability to collect and process information, acquire new knowledge, and analyze and solve problems, and effectively communication and cooperation (Ministry of Education of the People's Republic of China, 2001).

In 2019, the State Council issued the Opinions of the State Council on Deepening the Reform of Education and Teaching and Comprehensively Improving the Quality of Compulsory Education, stating that "the teaching methods should be optimized. Adhere to the teaching excellence, pay attention to heuristic, interactive, and inquiry-based teaching. Teachers should guide students before class Preview, the key points and difficulties, the knowledge system should be clarified in the class, and students should be guided to think actively, actively ask questions, and explore independently "(General Office of the State Council of the People's Republic of China, 2019). This is the first important document issued by the Central Government and the State Council to focus on education and teaching reform at the compulsory education stage. It is a programmatic document for deepening education and teaching reform in the new era and comprehensively improving the quality of compulsory education (People's Daily, 2019).

After eight times reforms, China's education and teaching concepts have undergone tremendous changes. The classroom has changed from knowledge transfer to students 'active learning, and "teaching and learning" has undergone profound changes (China Education News, 2019). As President Xi Jinping pointed out at the National Education Work Conference on September 18, 2018, after 40 years of exploration, we have a series of understanding of China's education reform and development, and our education concept has also developed to a new height (Xiang, 2019).

\section{Impact of the Largest Online Education Campaign}

The "School's Out, But Class's On" event, which was adopted because of the new crown epidemic, is the largest normal online education event in the history of modern education. In a teaching period of more than one and a half months, nearly 270 million colleges, high school, middle school and elementary school students in China have conducted normal course studies online. Nearly 20 million universities, high school, middle school, and elementary school teachers have carried out teaching activities through the Internet, creating the largest number of online students and refreshing the online concurrency of Internet use. "School's Out, But Class's On" is not just a crisis response plan, it is more like an exploration of a new type of education and teaching model in the spirit of reform (Wang, et al., 2020), by using modern information technology Transforming student learning methods and teacher teaching methods has an impact on the reconstruction of ecological education models in China and even worldwide. 


\section{Speed Up the Integration of Educational Technology and Teaching}

The Ministry of Education's "Notice on Coordinating and Coordinating Educational System COVID-19 Epidemic Situation and Educational Reform and Development Work" clearly states that "Schools conduct online education and teaching on a largescale and established basis during the epidemic prevention and control period. A test of the ability of major public health emergencies is of great significance to use information technology to promote education and teaching reform." (Ministry of Education of the People's Republic of China, 2020). "School's Out, But Class's On" is a test of the achievements of China's informatization construction, especially education informatization construction. The implementation of this activity proves that China's informatization construction has achieved world-renowned achievements, and it also proves that education informatization construction and its application have reached a new level.

Professor Dehuan Liu of Peking University once commented that this "largescale online live classroom is the largest experiment in the history of human education in 40 years." (ThePaper.cn, 2020). In this huge online teaching activity, the national basic education resources public service platform, China University MOOC and other mainstream MOOC platforms are meeting together with Alibaba, Tencent Education, ByteDance, Dongshi Ideal and other educational information enterprises to integrate all types of online education resources at all levels, to achieve full coverage of the platform, and share all resources.

Online learning breaks the limitation of study time and space and the limitation of the source flow of offline teaching students. It makes full use of the advantages of modern education technology to provide online education with high-quality, nondelayed, multi-form live interactive classrooms, and realizes live teaching in multiperson online classes. In online teaching, teachers use cutting-edge Internet technology to restore real teaching actions, and use massive electronic teaching resources to enrich teaching content, thereby realizing richer, practical and interesting live teaching (Luo, 2019). Students use the Internet to make learning choices more diverse and personalized, to make learning content and activities more free, and to make information technology and teaching more closely.

Online teaching is considered an important part of the future teaching model. However, since the emergence of online learning in 2013, online learning has not become one of the popular teaching formats in China (Wang, 2019). The successful launch of this large-scale online education activity provided valuable experience for the further implementation of online education, enriched people's understanding of online education, and increased the stickiness between educational technology and education and teaching. It is foreseeable that after the normal start of school, the use of the Internet for autonomous learning and after-school supplementary learning will become an important way for students to learn. Online teaching through the Internet will become 
an important form of teacher teaching, and teaching management using the Internet will also become an important form of school management.

\section{Promote The Reconstruction of Ecological Teaching Model}

The implementation of this large-scale online education objectively proves the effectiveness of China's education reform. The implementation of "School's Out, But Class's On" made all the people who are connected with education and rely on determination and inertia to stop at the old track (Wang, 2020). It changes the teaching environment under normal conditions, allowing teaching activities to move from offline to online, teacher's teaching from face-to-face to online cloud teaching, and student's learning from classroom listening to home-based autonomous learning. "School's Out, But Class's On" has completely changed the learning methods of students and the teaching methods of teachers, and has overturned the traditional teacher-centered teaching model in traditional teaching.

"School's Out, But Class's On" is not simply transplanting normal classroom teaching or offline education scenarios to the Internet platform. Its essence is a largescale and far-reaching education and teaching practice in China. Online education is a combination of modern education technology, education concepts and traditional education to form a new model suitable for educational needs (Ji \& Sun, 2019). In order to ensure the quality and effectiveness of online teaching, it is not only necessary to change the form of learning and teaching, but also to redesign the online teaching model (Wang, 2020). In the teaching process, taking the student as the center and the goal of promoting student development, teachers should select the corresponding digital education resources according to the nature of the discipline and the needs of student development, appropriately intervene and regulate the student's learning process, and rationally design and use learning activities to guide students to learn independently.

Therefore, the large-scale online education activities under the background of "School's Out, But Class's On" have stimulated the exploration of online teaching models and promoted the reconstruction of ecological teaching models. For students, online education promotes the transformation of learning models. Students have a more autonomous and personalized learning experience, allowing students to grasp the learning progress and choose the learning environment according to their own knowledge and ability level. For teachers, there is a need to rebuild the curriculum structure, improve teaching methods, and diversify classes. For schools, the new technology makes teaching management more effective, and also blurs the school's geographical boundaries, changes the structure of the school's curriculum, and makes it have the characteristics of "lead teacher + teaching assistants + technical staff".

The implementation of "School's Out, But Class's On" has brought new opportunities to China 's overall education reform, brought about new changes in teaching methods, learning methods, and management modes, and put forward new requirements.

\section{Promote the Integration of Home Education and School Educa- tion}


Affected by the epidemic, during the "School's Out, But Class's On" period, the teacher-student relationship and parent-child relationship encountered the modern dilemma with discrete time and space. Students cannot go to school to receive teacher guidance. In order to cooperate with their children's autonomous learning, many parents have supervised their children to study instead of teachers. Parents became important partners of students' autonomous learning during this special period. In this process, the relationship between parents and teachers was closer, and school education and family education were further integrated. "School's Out, But Class's On" really opened the way for family-school co-education.

Online learning during "School's Out, But Class's On” is not only an academic education, but also a "life education, belief education, science education, moral education" (Zheng, 2020). During the growth of students, 'School's Out, But Class's On' is not eager to master new knowledge of subjects in online courses, nor is it eager to take the opportunity to "overtake the peers", but to comprehensively improve the quality education of students to meet Students need to grow. At this stage, schools strengthen home-school ties, guide parents to establish a scientific concept of child rearing, learn scientific child rearing methods, and establish harmonious family relationships. Through home-school collaborative management, guide students to learn self-planning, independent learning, and self-management to achieve more valuable autonomous growth (Yu, 2020)."

Schools and families are indispensable subjects in the healthy growth of children. Building a harmonious home-school relationship and forming a pattern of cooperative education can guarantee children's healthy growth (People's Daily, 2019). The implementation of "School's Out, But Class's On" has provided more time and space for teacher-student relations and parent-child relationships, and has closer links between schools, families and students. This really promotes the integration of home education and school education, creates a good environment for students to learn independently, and promotes students to achieve more valuable growth.

\section{Conclusions}

In this sudden epidemic, the implementation of "School 's Out, But Class 's On" enabled 270 million students in China to learn online. Many places and schools across the country actively use the "cloud" technology to independently choose online live classrooms, online on-demand teaching, TV video learning and other methods for online teaching. Make full use of relevant national, local, and school-related teaching resources to provide online learning with rich, diverse, selectable, and high-quality online teaching resources covering all regions.

Such a large-scale, established system of online teaching activities is a test of China's education system facing major emergencies. The test results prove that China has basically completed the infrastructure of the Internet through the construction of informatization and education informatization in the past three decades. This provided the basic technical guarantee and resource guarantee for this large-scale online education. At the same time, through continuous deepening of education reforms, education 
and teaching concepts have been improved, and a "student-centric" education model has been basically established, creating possibilities for the occurrence of this online learning. Through the implementation of "School's Out, But Class's On", it has provided valuable experience for accelerating the integration of technology and education and for reforming the teaching methods of education in the new situation.

However, in the implementation process, online teaching also reflects some problems. For example, in online teaching, some teachers copy classroom teaching content to online teaching courses, ignoring subjective guidance, lacking teacher-student interaction, and poor teaching results. At the same time, some students, due to lack of self-control and self-learning ability, lacked face-to-face teacher or even parental supervision, online learning became a form, and the autonomous learning effect was not satisfactory. These questions put forward new requirements and new goals for online learning:

- How to better integrate technology and education;

- How to make students learn more autonomously in online teaching, teacher teaching is more effective, and online teaching models are more reasonable;

- How to make home education and school education more closely linked through online learning, these are the problems that need to be solved in online teaching.

\section{References}

Cai, H., Chen, M. (2019) Research on the construction and development of digital education resources in the intelligent age. Modern Dist Edu, (03): 74-81.

Chen, J. (2019) Digital China construction handed out dazzling "transcripts". Economic Daily, 05-07 (1).

China Economic Times. (2019) Broad prospects for the online education market.

https://baijiahao.baidu.com/s? Id=163479273

$2572824252 \& \mathrm{wfr}=$ spider $\&$ for $=\mathrm{pc}, 05-$ 29/2020-03-11

China Education Information Network. (2014) The Ministry of Education of the People's Republic of China and other five departments jointly issued the "Implementation Plan for the Construction of an Effective Mechanism to Expand the Coverage of
Quality Education Resources with Information Technology". pingxuan/n20141216_20967.shtml,1216/2020-03-11

China Education News. (2019) Striving for 70 Years of Service Education and Striving for a New Chapter-New China's 70-year Development History of Educational Equipment Industry. http://www.moe.gov.cn/jyb_xwfb/xw_zt/mo e_357/jyzt_2019n/2019_zt24 /cjzs/201910/t20191008_402174.html,1008/2020-03-11

China Education News. (2019) Teach the mechanics of solidifying the foundation industry-the development of 70 years of basic education reform in New China.

Http://www.moe.gov.cn/jyb_xwfb/s5147/20 
1909/t20190926_401046.html, 09 -26/202003-11

China Internet Network Information Center. (2019) The 43rd Statistical Report on Internet Development in China. http://www.cnnic.com.cn/hlwfzyj/hlwxzbg/h lwtjbg201902/P020190318523029756345,0 2-28/2020-03-11

China Xinhuanet. (2020) Xi Jinping's "2:23” Important Speech: The "Episode" Program Aiming for Victory.

Http://www.xinhuanet.com/politics/202002/25/c_1125625675.htm,02-23/2020-03-11

General Office of the State Council of the People's Republic of China. (2019) Opinions of the Central Committee of the Communist Party of China and the State Council on Deepening Educational Reform and Comprehensively Improving the Quality of Compulsory Education. 06-23.

Guangmingnet. (2020) Economic impact of new coronary pneumonia and policy suggestions. Https://theory.gmw.cn/202002/10/content_33541497.htm,02-10/202003-11

Guangzhou Municipal Education Bureau. (2020) Guidance for online education of elementary and middle schools (including secondary vocational schools) in Guangzhou.

Http://jyj.gz.gov.cn/yw/jyyw/content/post_5 682373.html,02-29/2020-03-11

Hu, Q. (2019) Review and Prospect: The Course and Future of the Development of Educational Informatization in China. E-learn Edu, (12): 5-13

Huang, R. (2018) Upgrading education informatization to help reform the education system. Chin Edu News, 05-19 (003)

Jin, J., Sun, C. Research on regional education reform supported by online educational learning platform. Chin Edu Inform, (16): 14-17

Leading group for prevention and control of pneumonia epidemic of COVID-19 infection in Zhejiang Provincial Department of Education. (2020) Guidance on the comprehensive implementation of online education and teaching in elementary and middle schools in the province during the delayed start of the school epidemic, 02-06 / 2020 -03-11
Leading Group of Cyber Security and Informatization of the Ministry of Education of the People's Republic of China. (2020) Summary of Educational Information and Cyber Security Work in 2019, 03-04

$\mathrm{Li}, \mathrm{C}$. (2007) The development process of basic education resource construction in China. Element Mid Sch Inform Technol Edu, (10): 5-6

Luo, T. Talking about the advantages and disadvantages of online teaching mode. Good Parent, (07): 153

Mei, H. (2018) Building a digital china: Seizing the opportunities in the new stage of information development. 08-19: 05

Ministry of Education of the People's Republic of China (2019) Overview of China's education-the development of national education in 2018.

http://www.moe.gov.cn/jyb_sjzl/s5990/2019 09/t20190929_401639.html,09-29/2020-0311

Ministry of Education of the People's Republic of China. (2001) Notice of the Ministry of Education of the People's Republic of China on Printing and Distributing the "Outline of Basic Education Curriculum Reform (Trial)" 06-08.

Ministry of Education of the People's Republic of China. (2012) State Councilor Liu Yandong's speech at a national teleconference on education informatization. http://www.gov.cn/ldhd/201209/05/content_2217594.htm,09-05/2020-0311

Ministry of Education of the People's Republic of China. (2012) Ten-year Development Plan for Education Informatization (20112020), 03-03

Ministry of Education of the People's Republic of China. (2015) "Full Coverage of Digital Education Resources in Teaching Sites" Project, 10-16

Ministry of Education of the People's Republic of China. (2018) Education Informatization 2.0 Action Plan, 04-18

Ministry of Education of the People's Republic of China. (2020) Deploying and coordinating the prevention and control of the new crown pneumonia epidemic in the education 
system and the reform and development of education, $02-28$

Ministry of Education of the People's Republic of China. (2020) Ministry of Education deploys in-depth work on "School 's Out, But Class 's On" elementary and middle schools, 03-06

Ministry of Education of the People's Republic of China. (2020) Notice on the Work Arrangement of "School 's Out, But Class 's On" during the elementary and middle schools postpone the start of 2020 spring semester, 02-12

Ministry of Education, People's Republic of China. (2020) There is no need to generally require teachers to record and broadcast courses. A person in charge of the Ministry of Education of the People's Republic of China answers questions about "School's Out, But Class's On”.

Http://www.moe.gov.cn/jyb_xwfb/s5147/20 2002/t20200212_420249.html,02-12/202003-11

National Working Group on Medium and Longterm Education Reform and Development Planning. (2010) National Medium and Long-term Education Reform and Development Planning Outline (2010-2020), 07-29

New Fortune. (2020) There is still a mystery behind the popularity of 1.4 billion people "s "online education" and "online office". Https://baijiahao.baidu.com/s?id=165828558 $3171742574 \& \mathrm{wfr}=$ spider $\&$ for $=\mathrm{pc}, 02-$ 12/2020-03-11

Notice of the Ministry of Education of the People's Republic of China (2020) Party Group of the Ministry of Education of the People's Republic of China on Coordinating and Doing a Good Job in the Prevention and Control of the New Crown Pneumonia Epidemic in the Education System and Education Reform and Development

People's Daily. (2019) Form a joint force of "home-school co-education". Http://edu.sina.com.cn/zxx/2019-04-14/docihvhiewr5654805.shtml?zw=edu,0404/2020-03-11

People's Daily. (2019) The Central Committee of the Communist Party of China and the State Council have issued a programmatic document on education and teaching reform in the compulsory education stage. 03-11.

People's Network. (2020) "China demonstrates the image of a responsible great country with practical actions" (see the truth and the common situation to combat the epidemic situation.)

Http://world.people.com.cn/n1/2020/0226/c1 002-31604381.html,02-26/2020-03-11

ThePaper.cn. (2020) Numbers | "School's Out, But Class's On", how is the response to large-scale online teaching at present? Https://baijiahao.baidu.com/s?id=165986536 $1939596296 \& \mathrm{wfr}=$ spider $\&$ for $=\mathrm{pc}, 02-$ 29/2020-03-11

Wang, Q. (2020) How can online learning be carried out efficiently? Fifth series of reports on "Prevention and Control of Epidemics and Guarding Students' Growth". Chin Edu Daily, 02-26

Wang, S. (2019) An analysis of the status quo of china's online education e-commerce platform and development countermeasures. ECommerce, (08): 69-70

Wang, Y., Huang, R, Yang, P., Wang, Y. (2019) 40 years of reform and opening up: the evolution and transcendence of education informatization from 1.0 to 2.0. Chin Med Edu Technol, 01 (33): 1-7

Wang, Z., Wu, Y., Liu, S. (2020) Online learning promotes teaching model reform. Chin Edu Daily, 02-22

Xia, J.P. (2020) Teaching for student learning: Exploration of teaching strategies based on protocol-guided learning. Sci Insigt Edu Front, 5(1):451-467.

Xiang, X. (2019) Retrospection and reflection on the 70-year reform of education concept in new China. J Nanjing Norm Univ (Soc Sci Ed), (02):15-29

Xinhuanet. (2000) The proposal of the Central Committee of the Communist Party of China on formulating the tenth five-year plan for national economic and social development. Http://news.sina.com.cn/china/2000-1018/136029.html,10-18/2020-03-11.

Xinhuanet. (2017) Report of the Work of the Eighteenth Central Discipline Inspection Commission to the Nineteenth National Congress of the Communist Party of China. 
http://www.xinhuanet.com/politics/201710/29/c_1121873020.htm,10-29/2020-03-11

Xinhuanet. (2019) The Ministry of Education of the People's Republic of China interprets "China Education Modernization 2035" and its implementation plan (2018-2022). Http://www.chinanews.com/gn/2019/0223/8762909.shtml,02-23/2020-03-11

Yang, Y. (2019) Review and experience summary of the 70-year development of informatization in new China. J Qiqihar Univ (Phil Soc Sci), (09): 36-40 + 44

Yu, M. (2020) How to teach "School's Out, But Class's On". Guangming Daily, 02-17

Zhao, Y. (2016) Development history, experience and reference of informatization at home and abroad. 01-08.

Zhejiang Provincial Department of Education and Research. (2020) The first large-scale online during the epidemic. On-line teaching survey report is coming! With 20 practical suggestions for online teaching in junior high school and high school https://www.sohu.com/a/375340691_689627 ,02-23/2020-03-11

Zheng, B. (2020) The ninth press conference on the prevention and control of new crown pneumonia in Henan Province.

Http://www.haedu.gov.cn/nyqfbh/index.html, 02-14/2020-03-11

Zhong, Z., Zeng, R., Zhang, X. (2017) Research on the evolution of China's educational informatization policy (1989--201 6 years). E-learn Edu Res, (09): 14-23

Zhu, Z. (2010) Progress report on China's basic education informatization. Chin Electr Edu, (09): 6-12. 